\title{
Effect of foliar spray with lithovit and amino acids on growth, bioconstituents, anatomical and yield features of soybean plant
}

\author{
M. M. M. Abd El-Aal and Rania S. M. Eid \\ Agricultural Botany Department, Faculty of Agriculture, Benha University, \\ Moshtohor, Toukh, Qalyoubia, 13736, Egypt \\ Corresponding Author: Mohamed.abdelal@fagr.bu.edu.eg
}

\begin{abstract}
A field study was carried out at the Experimental Farm Station of Faculty of Agriculture, Moshtohor, Benha University, Kalubia Governorate, Egypt, during the successive summer seasons of 2016 and 2017. This experiment was conducted to study the effect of foliar application with lithovit at 250 and 500 $\mathrm{mg} / \mathrm{l}$ and amino acids at 2 and $4 \mathrm{ml} / \mathrm{l}$ on some growth aspects, biochemical constituents, anatomical and yield characteristics of soybean plants cv. Giza 111. The obtained results indicated that foliar application with lithovit at a rate of $500 \mathrm{mg} / \mathrm{L}$ and amino acids at a rate of $4 \mathrm{ml} / \mathrm{l}$ caused significant increases in all vegetative growth characteristics expressed as plant height, stem diameter, number of leaves/ plant, total branches/plant, total leaf area/ plant, shoots fresh and dry weights $\mathrm{g} / \mathrm{plant}$ and specific leaf weight/plant as compared with the control treatment. Data also indicated that the application of lithovit at a rate of $500 \mathrm{mg} / \mathrm{l}$ and amino acids at $4 \mathrm{ml} / \mathrm{l}$ treatments gave the highest values of photosynthetic pigments (chlorophyll a, b and carotenoids), phytohormones concentration and leaf chemical compositions $(\mathrm{N}, \mathrm{P}, \mathrm{K}, \mathrm{Ca}, \mathrm{Mg} \%, \mathrm{Fe}$ ppm, total carbohydrates, crude protein \%) as well as enhancing leaf and stem anatomical features of soybean plant. Also, the obtained results showed that foliar application with lithovit at $500 \mathrm{mg} / 1$ and amino acids at $4 \mathrm{ml} / 1$ treatments caused significant increases in flowering and yield characteristics i.e., number of flowers/plant, number of setted pods/plant, pods yield/plant, number of seeds/pod, weight of seeds/pod, 100 seeds weight, weight of seeds/plant (g) in the two growing seasons as well as seeds oil percentage and unsaturated fatty acids \% as compared with the control.

Generally, it could be concluded that foliar application with growth stimulators as lithovit at $500 \mathrm{mg} / \mathrm{l}$ and amino acids at $4 \mathrm{ml} / \mathrm{l}$ could be recommend in soybean cultivation for improving its growth, productivity and quality.
\end{abstract}

Keywords: Soybean, Lithovit, amino acids, growth, chemical compositions, anatomy, yield and fatty acids.

\section{Introduction}

Soybean (Glycine max L.) is a legume and one of the most commonly cultivated crops in the world. Soybean seeds are an important source for human food, cooking oil and animal feed due to its content of the useful compounds such as unsaturated fatty acids, protein, mineral salts and plant secondary metabolites such as isoflavin. It is also used as feed, flour, soap, cosmetics, resins, paints, solvents and biodiesel, (Kim et al., 2016).

Nano-technology can consider and represent solution to increase the value of agricultural products and minimize environmental problems. With using nano-particles and nano-powders, we can produce controlled or delay released fertilizers. Nano-particles have high reactivity because of their more specific surface area, more density of reactive areas, or increased reactivity of these areas on the particle surfaces. These features simplify the absorption of fertilizers that produced in nano scale size, (Zhu $\boldsymbol{e t}$ al., 2008).

Nano-fertilizers are used recently as an alternative to conventional fertilizers for slow release and efficient use by plants. Nano-fertilizers could enhance nutrient use efficiency and decrease the costs of environmental protection, (Naderi and Danesh Shahraki, 2013).
Previous studies showed that nano-particles can be beneficial for growth and development of plant, (Khaledian et al., 2014).

Lithovit is a natural calcium carbonate (nano$\mathrm{CaCO}_{3}$ ) foliar fertilizer supplemented with calcium which delivers fine particles $(<10 \mu \mathrm{m})$ that can easily be adsorbed directly through the stomata of plant leaves. The micronutrients supplied with lithovit influence plant metabolism and cell wall formation $\mathrm{Ca}$ ), resulting in a product that has potential to increase and sustain improved plant metabolism. Inside the leaf intercellular spaces lithovit particles break down and release gaseous $\mathrm{CO}_{2}$ enhancing the $\mathrm{CO}_{2}$ concentration at the photo-synthetically active area within the plant leaves. The normal concentration of $\mathrm{CO}_{2}$ in the atmosphere is approximately $0.04 \mathrm{vol} . \%$, which means that most cultivated plants fail to achieve the optimum level of photosynthetic rate, which is achieved at near to 0.1 vol. \% $\mathrm{CO}_{2}$. The lithovit particles that enter the intracellular "compartment" dock, with its negative surface of the cell membrane, where they produce a negative potential. Lithovit's mode of action is to increase $\mathrm{CO}_{2}$ levels within the plant leaf structure and by implication enhance photosynthetic efficiency. The additional supply of micronutrients from the lithovit complex provides a source of key plant 
available elements required to aid photosynthetic activity, (Thorn and Rogan, 2015).

Also, Lithovit contains nano-Iron which is one of the essential elements for plant growth and plays an important role in the photosynthetic reactions. Iron activates several enzymes and contributes to RNA synthesis and improves the performance of photosystems, (Malakouti and Tehrani, 2005). (Sheykhbaglou et al., 2010) on soybean plant concluded that nano-iron oxide increased leaf and pod dry weight. The highest grain yield was observed with using nano-iron oxide that showed $48 \%$ increase in grain yield in comparison with control.

Lithovit also contains nano-Mg, magnesium is an essential nutrient for plant growth and plays an important role in many plant physiological processes such as photosynthesis ( $\mathrm{Mg}$ is the central element of the chlorophyll molecule), sugar synthesis, starch translocation, formation of plant oils and fats, control of nutrient uptake, increase iron utilization and aid nitrogen fixation in legume nodules. It also works as an enzyme activator, a constituent of many enzymes and a carrier of phosphorus in the plant, (Marschner, 1995; Allison et al., 2001 and Haq and Mallarino 2005).

Lithovit has a very significant positive influence on the growth i.e. stem height, crown diameter, and leaves number of Zea maize (Azevedo Neto et al., 2005; Koelreuteria paniculata Sabina 2013; Triticum aestivum Maswada and Abd El-Rahman 2014; Hayward kiwifruit Thorn and Rogan 2015 and Lycopersicon esculentum MoisăR 2015). In addition, Abdel Nabi et al., (2017) recommended that foliar spraying of lettuce plants with nano materials (lithovit at the rate of $0.5 \mathrm{~g} /$ liter) gave the maximum means of all studied characters as total leaf area, total yield and dry matter percentage . Also, it gave the highest values of total soluble solids (TSS), total sugars, total carbohydrates, crude protein percentages, chlorophyll a, b and total chlorophylls content.

Amino acids are organic molecules that contain nitrogen, carbon, hydrogen and oxygen and have an organic side chain in their structure, a characteristic that distinguishes the different amino acids, (Buchanan et al., 2000). Amino acids can play different roles in plants; they can act as stressreducing agents, source of nitrogen and hormone precursors, (DeLille et al., 2011; Maeda and Dudareva 2012. Also, Sadak et al., 2015) indicated that amino acid application as foliar spray significantly improved all the parameters (shoot length, number of leaves per plant, fresh and dry weight of shoots, photosynthetic pigments, total carbohydrates, polysaccharides, nucleic acid DNA and RNA contents and also, increased of $\mathrm{K}^{+}, \mathrm{K}^{+}: \mathrm{Na}^{+}$, $\mathrm{Ca}^{2+}, \mathrm{Mg}^{2+}$ and $\mathrm{P}$ contents of faba bean leaves.

The importance of amino acids, that build blocks for proteins, cannot be overlooked. Besides their role as protein constituents; amino acids are also involved in a plethora of cellular reactions and therefore, they influence a number of physiological processes such as plant growth and development, intracellular $\mathrm{pH}$ control, generation of metabolic energy or redox power and resistance to both abiotic and biotic stress, (Pratelli and Pilot, 2014). Also, amino acids are known as biostimulant which have positive effects in plant growth and yield, (Kowalczyk and Zielony, 2008). (Saeed et al., 2005) on soybean found that treating plants with amino acids significantly improved growth parameters of shoots and fresh weights as well as pods yield. (Liu Xing et al., 2008) revealed that foliar application with a mixture of amino acids to radish plants increased $\mathrm{N}$ content of shoots. El(Zohiri and Asfour, 2009) on potato found that spraying amino acids significantly increased vegetative growth as plant height and dry weights. (Abo Sedera et al., 2010) revealed that spraying strawberry plants with amino acids significantly increased total nitrogen, phosphorus and potassium in plant foliage as well as total fruit yield, TSS, vitamin $\mathrm{C}$ and total sugars content of fruits compared to control.

Therefore, the present work aimed to evaluate the effect of foliar application of lithovit $(\mathrm{Ca}, \mathrm{Mg}$ and $\mathrm{Fe}$ nano or micro particles) fertilizer and amino acids on the growth, chemical constituents, anatomical and yield characteristics of soybean plant.

\section{Material and Methods}

A field study was carried out at the Experimental Farm Station of the Faculty of Agriculture, Moshtohor, Benha University, Kalubia Governorate, Egypt, during the two successive summer seasons of 2016 and 2017 to investigate the effect of growth stimulator materials: lithovit at 250 and $500 \mathrm{mg} / \mathrm{l}$ and amino acids (delfan) at 2 and $4 \mathrm{ml} / \mathrm{l}$ on growth, chemical constituents, anatomical and yield characteristics of soybean plant $\mathrm{Cv}$. Giza 111. Seeds of soybean (Glycine $\max$ L.) were obtained from Agricultural Research Center, Ministry of Agriculture, Giza, Egypt.

Lithovit is used as nano particales $(\mathrm{Ca}, \mathrm{Mg}$ and $\mathrm{Fe}$ nano particles) compound containing calcium carbonate $(80 \%)$, magnesium carbonate $(4.6 \%)$ and $\mathrm{Fe}(0.75 \%)$, (Carmen et al., 2014).

DELFAN $10 \%$ L- $\alpha$ free amino acids is a liquid with $\mathrm{pH}$ of 5-5.5 and specific gravity of $1.12 \mathrm{~g} / \mathrm{mL}$. Also, it contains $18.4 \%$ w/w Organic matter, $10 \%$ $\mathrm{w} / \mathrm{w}$ free amino acids, $3 \% \mathrm{w} / \mathrm{w}$ total nitrogen and $3 \%$ w/w organic nitrogen was used as a source for amino acids mixture. It is produced by Trade Corporation International Company, Madrid and imported by Techno Green Comp. Group, Cairo, Egypt.

Delfan amino acid contents (g amino acids/ $100 \mathrm{~g}$ muestra) as follows: 


$\begin{array}{llllll}\text { aspartic } & 2.3 & \text { glutamic } & 4.2 & \text { serine } & 2.8 \\ \text { glycine } & 4.6 & \text { histidine } & 0.3 & \text { argnine } & 2.6 \\ \text { threionine } & 1.2 & \text { alanine } & 2.5 & \text { proline } & 2.8 \\ \text { tyrosine } & 0.9 & \text { cystine } & 0.2 & \text { valine } & 1.8 \\ \text { methionine } & 0.2 & \text { isoleucine } & 1.1 & \text { leucine } & 2.1 \\ \text { phenylalanine } & 1.1 & \text { hidroxiproline } & 2.7 & \text { lysine } & 1.1\end{array}$

Seeds of soybean were sown on $15^{\text {th }}$ May in the two successive seasons, in open field. Four seeds/hill were sown at $3 \mathrm{~cm}$ depth on one side of the ridge at $25 \mathrm{~cm}$ apart, after complete germination (21 days after sowing in both seasons) plants were thinned into two plants per hill.

The experimental unit was $(3 \times 3.5)$ meter including five rows. Calcium superphosphate $(15.5 \%$ $\left.\mathrm{P}_{2} \mathrm{O}_{5}\right)$ and potassium sulphate $\left(48 \% \mathrm{~K}_{2} \mathrm{O}\right)$ were added before sowing in both seasons at the rates of 100 and $50 \mathrm{~kg} / \mathrm{fed} \mathrm{respectively.} \mathrm{Also,} \mathrm{nitrogen} \mathrm{fertilizer} \mathrm{at}$ rate of $20 \mathrm{~kg} / \mathrm{fed}$. was applied before the first irrigation in form of urea $(46 \% \mathrm{~N})$. The other cultural practices for growing soybean plants were carried out as recommended by Egyptian ministry of agriculture. The experiment was arranged in a randomized complete block design with five replicates.

The experimental treatments were five treatments i.e., lithovit at 250 and $500 \mathrm{mg} / \mathrm{l}$ and amino acids at 2 and $4 \mathrm{ml} / \mathrm{l}$ in addition to the control treatment (distilled water). Plants were sprayed three times after 30, 50 and 70 days from sowing using hand operated compressed air sprayer.

\section{Sampling and collecting data}

\section{Growth characteristics:}

Ten plants from each treatment were randomly taken at 85 days after sowing to measure plant growth characteristics i.e., plant height, stem diameter, number of leaves and branches/plant, fresh and dry weights of shoots (Leaves and stems) /plant, total leaf area/ plant $\left(\mathrm{cm}^{2}\right)$, specific leaf weight /plant $\left(\mathrm{mg} / \mathrm{cm}^{2}\right)$. The samples of the vegetative parts were dried in the oven for $48 \mathrm{~h}$ at $75^{\circ} \mathrm{C}$ to a constant weight and then the dry weight per plant was calculated. These dry samples of leaves were kept for chemical analyses.

\section{Chemical compositions:}

\subsection{Photosynthetic pigments:}

Chlorophyll a, b and carotenoids were colorimetrically determined in leaves of soybean plants at 85 days after sowing during 2016 and 2017 seasons according to the methods described by (Wettestein, 1957) and calculated as $\mathrm{mg} / \mathrm{g}$ fresh weight.

\subsection{Determination of leaf mineral concentrations:}

Total nitrogen was determined by using microkjeldahl method as described by (Horneck and Miller, 1998); phosphorus and potassium were determined according to (Sandell, 1950) and Horneck and Hanson (1998), respectively.

Leaves crude protein was calculated according to the following equation: Crude protein = Total nitrogen x 6.25 (A.O.A.C., 2005). Total carbohydrates were determined according to the method described by (Dubois et al., 1956).

Determination of calcium and magnesium in soybean leave digests were carried out by using ammonium versinate parporate and erichrome black $\mathrm{T}$ as indicator according to (Jackson, 1967). Also, iron was determined by using the atomic absorption spectorophotometer (Perkin Elmer 3110).

\subsection{Endogenous Phytohormones:}

Endogenous phytohormones were quantitatively determined in Glycine max L. shoots at 85 days after sowing during season 2017 using High- Performance Liquid Chromato-graphy (HPLC) according to (Koshioka et al., 1983) for auxin (IAA), gibberellins and abscisic acid (ABA), while cytokinins were determined according to (Nicander et al., 1993).

\subsection{Determination of seed oil concentration: \\ 2.4.1. Crude Fat:}

Oil percentage was extracted by Soxlet apparatus using petrolium ether as a solvent according to (A.O.A.C., 2005).

\subsubsection{Fatty Acids:}

Fractionation, identification and quantification of different fatty acids of soybean seeds oil were carried out during season of 2017. The fatty acids were converted to methyl esters according to (Sink et al., 1964). The fatty acids methyl esters were analyzed using Gas Liquid Chromatography (GLC)/HP (6890) GC capillary equipped with flame ionization detectors and coiled glass column each (DB-23 capillary column), Dimension:60 $\mathrm{m} \times 0.32 \mathrm{~mm} \times$ $0.25 \mu \mathrm{m}$.

\subsection{Anatomical studies:}

The samples of stems and leaves were taken from the $4^{\text {th }}$ internode from top of the main stem of all treatments at 85 days after sowing during season 2017. The samples specimens were taken, then killed and fixed in FAA, washed in 50\% ethyl alcohol, dehydrated in series of ethyl alcohols, infiltrated in xylene, embedded in paraffin wax with a melting point of $60-63^{\circ} \mathrm{C}$, sectioned to 20 microns in thickness according to (Sass, 1951) stained with the double stain method, cleared in xylene and mounted in Canada balsam according to (Johanson, 1940). Sections were read to detect histological 
manifestation of any noticeable responses resulted from the applied treatments.

\subsection{Flowering, yield and its components: 2.6.1.Flowering characteristics:}

Ten plants per each treatment were randomly chosen and labeled in the field from the start of flowering to harvest time and the following characters were studied and recorded:

a) No. of opened flowers/ plant: Counting was started at 60 days of plant age with 3 days intervals until 100 days.

b) No. of setted pods/ plant: Counting was started at 75 days of plant age with 3 days intervals until 125 days.

c) No. of survived (mature) pods/ plant: It was recorded at harvest time.

d) $\%$ of flower shedding $=$

Total No. of flowers/plant - No. of setted pods/plant

Total No. of flowers/plant

x 100

\subsubsection{Yield and its components:}

At harvest, samples were taken at 125 days after sowing from each treatment to estimate yield characters, i.e., number of setted pods/plant, pods weight/plant, number of seeds/pod, weight of seeds/pod, 100 seeds weight $(\mathrm{g})$, seeds yield/plant (g).

\section{Statistical Analysis}

The obtained data in both seasons of study were subjected to analysis of variance as a simple experiment in randomized complete block design. LSD was used to evaluate the differences between means according to (Snedecor and Cocharn, 1991).

\section{Results and Discussion}

\section{Vegetative growth characteristics:}

Data in Table (1) indicate that spraying soybean plants with lithovit at $250,500 \mathrm{mg} / \mathrm{l}$ and amino acids at 2 and $4 \mathrm{ml} / 1$ three times during the growing seasons significantly increased all measured growth aspects i.e., plant height, stem diameter, number of leaves, branches/plant and total leaf area per plant as well as fresh and dry weights of shoots (leaves and stems) compared with the control treatment in both seasons 2016 and 2017. In this connection, generally the highest values of these parameters were recorded as a result of spraying plants with the highest used concentrations of lithovit at $500 \mathrm{mg} / \mathrm{l}$ and amino acids at $4 \mathrm{ml} / \mathrm{l}$ in comparison with the other treatments and control plants. Also, the increases in plant growth traits as a result of using biostimulators may be attributed to the increases of photosynthetic pigments and the absorption of mineral nutrients. In this regard, on snap bean plants, (El- Atabany, 2015) found that spraying snap bean plant with micronized calcium carbonate significantly increased all measured growth aspects expressed as plant height, number of leaves plant, fresh and dry weights as well as leaf area/plant compared with the control.

Lithovit application improves photosynthesis process that may be related to its high content of carbonates, as source of $\mathrm{CO}_{2}$ and calcium. However, it was found that elevated $\mathrm{CO}_{2}$ and exogenous calcium application have positive effects on photosynthesis improvement. Also, lithovit acts as a long term reservoir supplying plants with $\mathrm{CO}_{2}$; thus it can enhance growth of plants, particularly $\mathrm{C}_{3}$ plants as wheat and cotton by increasing $P_{n}$ (photosynthesis net) because higher $\mathrm{CO}_{2}$ can suppress ribulose-1,5-bisphosphate (RuBP) oxygenase activity; decrease photorespiration; and increase carbon assimilates for plant growth and development. Elevated $\mathrm{CO}_{2}$ concentrations generally increase plant growth through increased carbon assimilation, biomass and leaf area of plants, (Maswada and Abd El-Rahman, 2014).

(Abo Basha and El-Aila, 2015) reported that spraying the radish plants with amino acids had statistically effect on fresh and dry weights of shoot and root, root length and diameter as well as nutrients content and uptake. The obtained results are in agreement with those of (Zewail, 2014) who demonstrated that foliar application with amino acids at $4 \mathrm{ml} / \mathrm{l}$ increased estimated growth characteristics i.e., plant height, stem diameter, number of branches and leaves/ plant, total leaf area /plant, dry weight of shoots and specific growth rate of common bean plant. (Sadak et al., 2015) reported that amino acids are well known biostimulant which have positive effects on plant growth of faba bean plant besides they play a key role in secondary metabolism in plants, (Hildebrandt et al., 2015).

\section{Leaf chemical compositions:}

\subsection{Photosynthetic pigments}

Data presented in Table (2) show that the concentration of chlorophyll a, b, total chlorophyll and carotenoids of plants sprayed with lithovit at 250, $500 \mathrm{mg} / \mathrm{l}$ and amino acids at 2 and $4 \mathrm{ml} / \mathrm{l}$ were increased compared with control plants.

This is may be due to lithovit particles can enhance the growth of crops by means of increasing the natural photosynthesis. Such results are connected with those reported by (Maswada and Abd El-Rahman, 2014; Agrawal and Deepak, 2003 and Wang et al., 2013). (Carmen et al., 2014) suggested that lithovit fertilizer particles sprayed on tomato plants were absorbed and transformed into $\mathrm{CO}_{2}$. Therefore, lithovit fertilizer could significantly enhance photosynthesis because the external factor that limit photosynthesis is the natural content of $\mathrm{CO}_{2}$ in the air. Also, (Maswada and Abd ElRahman, 2014) showed that lithovit treatment significantly increased total chlorophyll and total carotenoids of wheat plant. 
Table 1. Effect of lithovit and amino acids on some growth characteristics of soybean plants at 85 days after sowing during 2016 and 2017 seasons.

\begin{tabular}{|c|c|c|c|c|c|c|c|c|c|c|c|}
\hline Characteristics & $\begin{array}{l}\text { Plant } \\
\text { height } \\
(\mathrm{cm})\end{array}$ & $\begin{array}{c}\text { Stem } \\
\text { diameter } \\
(\mathrm{cm})\end{array}$ & $\begin{array}{c}\text { Number of } \\
\text { total } \\
\text { branches } \\
\text { /plant }\end{array}$ & $\begin{array}{c}\text { Number of } \\
\text { leaves } \\
\text { /plant }\end{array}$ & $\begin{array}{c}\text { Stem } \\
\text { fresh } \\
\text { weight } \\
\text { g/plant }\end{array}$ & $\begin{array}{c}\text { Leaves } \\
\text { fresh } \\
\text { weight } \\
\text { g/plant }\end{array}$ & $\begin{array}{c}\text { Main stem } \\
\text { and } \\
\text { branches } \\
\text { dry weight }\end{array}$ & $\begin{array}{c}\text { Leaves } \\
\text { dry } \\
\text { weight } \\
\text { g/plant }\end{array}$ & $\begin{array}{l}\text { Total dry } \\
\text { weight } \\
\text { g/plant }\end{array}$ & $\begin{array}{l}\text { Total leaf } \\
\text { area /plant } \\
\left(\mathrm{cm}^{2}\right)\end{array}$ & $\begin{array}{c}\text { Specific leaf } \\
\text { weight /plant } \\
\left(\mathrm{mg} / \mathrm{cm}^{2}\right)\end{array}$ \\
\hline Treatments & \multicolumn{11}{|c|}{$1^{\text {st }}$ season (2016) } \\
\hline Control & 98.2 & $0 . .9$ & 8.3 & 51.1 & 88.9 & 118.2 & 19.2 & 25.3 & 44.5 & 2456.53 & 10.30 \\
\hline Lithovit at $250 \mathrm{mg} / \mathrm{l}$ & 119.5 & 1.2 & 9.9 & 80.5 & 112.2 & 142.3 & 31.1 & 37.2 & 68.3 & 3160.68 & 11.77 \\
\hline Lithovit at $500 \mathrm{mg} / \mathrm{l}$ & 131.7 & 1.3 & 14.1 & 97.0 & 128.6 & 178.2 & 38.3 & 48.1 & 86.4 & 4125.41 & 11.66 \\
\hline Amino acids at $2 \mathrm{ml} / \mathrm{l}$ & 107.4 & 1.1 & 11.4 & 69.4 & 109.2 & 147.6 & 29.5 & 34.1 & 63.6 & 2907.61 & 11.73 \\
\hline Amino acids at $4 \mathrm{ml} / \mathrm{l}$ & 124.0 & 1.3 & 12.3 & 93.7 & 121.4 & 153.0 & 33.3 & 45.9 & 79.2 & 3014.25 & 15.23 \\
\hline \multirow[t]{2}{*}{$\begin{array}{ll}\text { L.S.D. } & 0.05 \\
\end{array}$} & 7.35 & 0.14 & 1.12 & 10.84 & 13.09 & 21.05 & 5.40 & 7.16 & 8.73 & 219.98 & 0.26 \\
\hline & \multicolumn{11}{|c|}{$2^{\text {nd }}$ season (2017) } \\
\hline Control & 107.7 & 1.1 & 10.4 & 64.0 & 103.6 & 91.6 & 23.9 & 28.5 & 50.4 & 2454.46 & 11.61 \\
\hline Lithovit at $250 \mathrm{mg} / \mathrm{l}$ & 116.2 & 1.3 & 12.0 & 68.9 & 123.6 & 117.8 & 31.1 & 35.1 & 66.2 & 2878.73 & 12.19 \\
\hline Lithovit at $500 \mathrm{mg} / \mathrm{l}$ & 128.6 & 1.4 & 13.3 & 82.5 & 138.7 & 197.3 & 36.0 & 39.5 & 75.5 & 3377.02 & 11.70 \\
\hline Amino acids at $2 \mathrm{ml} / \mathrm{l}$ & 112.2 & 1.2 & 11.2 & 67.3 & 120.9 & 132.0 & 30.8 & 31.9 & 62.7 & 2704.95 & 11.79 \\
\hline Amino acids at $4 \mathrm{ml} / 1$ & 127.3 & 1.3 & 12.6 & 79.2 & 126.1 & 162.1 & 32.2 & 34.4 & 66.6 & 3154.52 & 10.90 \\
\hline L.S.D. & 5.92 & 0.11 & 1.03 & 3.12 & 16.84 & 18.27 & 7.04 & 3.09 & 8.50 & 288.17 & 0.17 \\
\hline
\end{tabular}

Table 2. Effect of lithovit and amino acids on photosynthetic pigments (mg/g F.W.) of soybean leaf at 85 days after sowing during 2016 and 2017 seasons.

\begin{tabular}{|c|c|c|c|c|c|c|}
\hline \multirow{3}{*}{$\begin{array}{l}\text { Characteristics } \\
\text { Treatments }\end{array}$} & \multicolumn{4}{|c|}{ Chlorophyll } & \multicolumn{2}{|c|}{ Carotenoids } \\
\hline & $\begin{array}{l}\text { Chl. a } \\
\text { mg/g F.W. }\end{array}$ & $\begin{array}{c}\text { Chl.b } \\
\text { mg/g F.W. }\end{array}$ & $\begin{array}{l}(a+b) \\
\text { mg/g F.W. }\end{array}$ & $\begin{array}{c}(\mathrm{a}+\mathrm{b}) \% \text { relative } \\
\text { to the control }\end{array}$ & $\mathrm{mg} / \mathrm{g}$ F.W. & $\begin{array}{c}\% \text { relative to the } \\
\text { control }\end{array}$ \\
\hline & \multicolumn{6}{|c|}{$1^{\text {st }} \operatorname{season}(2016)$} \\
\hline Control & 1.116 & 0.877 & 1.993 & 100.00 & 1.230 & 100.00 \\
\hline Lithovit at $250 \mathrm{mg} / \mathrm{l}$ & 1.135 & 0.946 & 2.081 & 104.42 & 1.313 & 106.75 \\
\hline Lithovit at $500 \mathrm{mg} / \mathrm{l}$ & 1.605 & 1.211 & 2.816 & 141.29 & 1.822 & 148.13 \\
\hline Amino acids at $2 \mathrm{ml} / 1$ & 1.209 & 0.864 & 2.073 & 104.01 & 1.794 & 145.85 \\
\hline \multirow[t]{2}{*}{ Amino acids at $4 \mathrm{ml} / \mathrm{l}$} & 1.208 & 0.941 & 2.149 & 107.83 & 1.514 & 123.09 \\
\hline & \multicolumn{6}{|c|}{$2^{\text {nd }} \operatorname{season}(2017)$} \\
\hline Control & 1.116 & 0.684 & 1.800 & 100.00 & 0.827 & 100.00 \\
\hline Lithovit at $250 \mathrm{mg} / \mathrm{l}$ & 1.132 & 0.793 & 1.925 & 106.94 & 0.946 & 114.39 \\
\hline Lithovit at $500 \mathrm{mg} / \mathrm{l}$ & 1.605 & 0.872 & 2.477 & 137.61 & 0.984 & 118.98 \\
\hline Amino acids at $2 \mathrm{ml} / 1$ & 1.209 & 0.761 & 1.970 & 109.44 & 0.924 & 111.73 \\
\hline Amino acids at $4 \mathrm{ml} / 1$ & 1.428 & 0.812 & 2.240 & 124.44 & 0.941 & 113.78 \\
\hline
\end{tabular}


In addition, (Zewail, 2014) indicated that foliar application with amino acids at $4 \mathrm{ml} / \mathrm{l}$ increased photosynthetic pigments and total chlorophyll SPDS of common bean. Also, (El- Atabany, 2015) reported that spraying snap bean plants with the growth stimulant lithovit increased photosynthetic pigments (chlorophyll a, b, total chlorophyll and carotenoids). Also, (Shallan et al., 2016) showed that spraying cotton plants with lithovit (nano$\mathrm{CaCO}_{3}$ ) fertilizer caused increases of pigment contents. In this regard, (Abd El Ghafer et al., 2016) mentioned that foliar application with lithovit significantly increased chlorophyll and carotenoids of onion plant. Also, (Abdel Nabi et al., 2017) revealed that foliar spraying lettuce plants with nano materials (lithovit) gave the highest values of chlorophyll a, b and total chlorophyll contents.

\subsection{Nutrient, protein and carbohydrate \%:}

Data in Table (3) clearly indicate that minerals $\left(\mathrm{N}, \mathrm{P}, \mathrm{K}, \mathrm{Ca}, \mathrm{Mg} \%\right.$ and $\mathrm{Fe} \mathrm{mg} \mathrm{kg}^{-1}$ ), total carbohydrates and crude protein $\%$ in soybean leaves highly increased with different applied treatments during 2017 season at 85 days after sowing compared with those of the control. The same data cleared that the most effective treatments which maintained the highest values were amino acids at 4 $\mathrm{ml} / \mathrm{l}$ treatment followed by lithovit at $500 \mathrm{mg} / \mathrm{l}$ and amino acids at $2 \mathrm{ml} / \mathrm{l}$, respectively compared with the control.

In this respect, the increases in nutrients, total carbohydrates and protein \% with different applied treatments are considered as a direct result of increasing both photosynthesis rate and efficiency (Table,2) also, that was preceded with large photosynthetic area (Table,1) as well as enhancement of minerals translocation from roots to leaves. In addition, increments of those bioconstituents in soybean leaves with different applied treatments considered a direct result of the obtained vigorous growth, thereby, plants with this case of growth and entire feeding system could be give high yield with high quality.

Our results indicate that the application of lithovit and amino acids as a foliar spray caused increases in the content of soybean leaf bioconstituents.

Such results showed similar trend to those obtained by many investigators worked on nanofertilizers and amino acids. In this concern, amino acids have a chelating effects on micronutrient, that make the absorption and transportation of micronutrients inside the plant easier due to its effect on cell membrane permeability, (Marschner, 1995). (Abo Sedera et al., 2010) revealed that spraying strawberry plants with amino acids significantly increased total nitrogen, phosphorus and potassium in plant foliage as well as total sugars content of fruits compared with control treatment. Also, (Zewail, 2014) indicated that foliar application with amino acids at $4 \mathrm{ml} / \mathrm{l}$ increased biochemical constituents $\mathrm{N}, \mathrm{P}, \mathrm{K}, \mathrm{Mg}, \mathrm{Ca}, \mathrm{Fe}, \mathrm{Zn}$, total carbohydrates and crude protein of common bean leaves. (Sadak $\boldsymbol{e t}$ al., 2015) reported that amino acid application as foliar spray significantly induced higher contents of total carbohydrates, polysaccharides, total protein, $\mathrm{K}^{+}, \mathrm{Ca}^{2+}, \mathrm{Mg}^{2+}$ and $\mathrm{P}$ contents of faba bean leaves.

Similar promoting effects of lithovit were observed by other investigators, The use of nano calcium carbonate on peanut plants increased the soluble sugar and protein, (Liu et al., 2005). (Tousi et al., 2014) concluded that spray application of nano-Fe chelate increased the quality of soybean plant. (Shallan et al., 2016) showed that pretreatment of cotton plants with lithovit (nano$\mathrm{CaCO}_{3}$ ) fertilizer caused increases in total soluble sugars and total soluble protein contents.

Table 3. Effect of lithovit and amino acids on some nutrients, total carbohydrates and crude protein $\%$ in soybean leaf during 2017 season.

\begin{tabular}{|c|c|c|c|c|c|c|c|c|}
\hline \multirow{2}{*}{$\begin{array}{l}\text { Characteristics } \\
\text { Treatments }\end{array}$} & \multicolumn{6}{|c|}{ Nutrients in leaves } & \multirow{2}{*}{$\begin{array}{c}\text { Crude } \\
\text { protein } \%\end{array}$} & \multirow{2}{*}{$\begin{array}{c}\text { Total } \\
\text { carbohydrates \% }\end{array}$} \\
\hline & N\% & $\mathrm{P} \%$ & $\mathrm{~K} \%$ & $\mathrm{Ca} \%$ & $\mathrm{Mg} \%$ & $\begin{array}{l}\text { Fe mg } \\
k^{-1}\end{array}$ & & \\
\hline Control & 3.21 & 0.34 & 2.15 & 1.15 & 0.25 & 54 & 20.06 & 53.25 \\
\hline Lithovit at $250 \mathrm{mg} / 1$ & 3.68 & 0.45 & 2.55 & 2.91 & 0.35 & 73 & 23.00 & 55.75 \\
\hline Lithovit at $500 \mathrm{mg} / 1$ & 3.71 & 0.47 & 2.58 & 3.00 & 0.39 & 80 & 23.19 & 57.50 \\
\hline Amino acids at $2 \mathrm{ml} / 1$ & 3.82 & 0.47 & 2.80 & 1.70 & 0.33 & 64 & 23.88 & 54.88 \\
\hline Amino acids at $4 \mathrm{ml} / \mathrm{l}$ & 3.90 & 0.48 & 2.86 & 1.80 & 0.36 & 68 & 24.38 & 56.63 \\
\hline
\end{tabular}

\section{Endogenous phytohormones:}

Data in Table (4) illustrate the effect of spraying soybean plants with Lithovit at $250,500 \mathrm{mg} / \mathrm{l}$ and amino acids at 2 and $4 \mathrm{ml} / \mathrm{l}$ on endogenous phytohormones during the growing season of 2017. The obtained results indicate that foliar application with amino acids at $4 \mathrm{ml} / \mathrm{l}$ and lithovit at $500 \mathrm{mg} / \mathrm{l}$ caused highly increases in the endogenous growth promoters and decreases in growth inhibitor substance may be attributed to their effects on enhancing the biosynthesis of growth promoters and decreasing the biosynthesis and action of growth inhibitor (ABA) compared with the control treatment.

In general, total phytohormones that promote growth aspects (i.e., growth promoters, auxins, 
gibberellins and cytokinins) increased with all applied treatments. Also, amino acids at $4 \mathrm{ml} / 1$ gave the highest value of total promoters followed by lithovit at $500 \mathrm{mg} / \mathrm{l}$ in soybean shoots during 2017 season. Such increases in growth promoters (IAA, $\mathrm{GA}_{3}$ and cytokinins) in shoots of soybean treated with biostimulators (amino acids and lithovit) were in parallel with the increase in growth (Table,1) and yield characters (Table,7). That may be attributed to the stimulation in cell division as well as enlargement. These results are in agreement with the results of (Schwab and Raab, 2004) who suggested that spraying the plants with amino acids stimulated cytokinins and auxins content of strawberry plant. Also, (El-Ghamry et al., 2009) pointed out that amino acids could directly or indirectly influence the physiological activities of plant growth and development through their regulatory effects in production of phytohormones in plant tissues.

Table 4. Effect of lithovit and amino acids on endogenous phytohormones concentration ( $\mu \mathrm{g} / \mathrm{g}$ F.W.) in shoots of soybean at 85 days after sowing during 2017 season.

\begin{tabular}{|c|c|c|c|c|c|c|c|}
\hline \multirow{2}{*}{ Plant hormones } & \multicolumn{5}{|c|}{ Promoters $\mu \mathrm{g} / \mathrm{g}$ F.wt } & \multicolumn{2}{|c|}{ Inhibitors } \\
\hline & $\begin{array}{c}\text { Gibberellins } \\
\mu \mathrm{g} / \mathrm{g} \text { F.wt }\end{array}$ & $\begin{array}{c}\text { Auxins } \\
\mu \mathrm{g} / \mathrm{g} \\
\text { F.wt. }\end{array}$ & $\begin{array}{l}\text { Cytokinins } \\
\mu \mathrm{g} / \mathrm{g} \text { F.wt }\end{array}$ & $\begin{array}{c}\text { Total } \\
\text { Promoters } \\
\mu \mathrm{g} / \mathrm{g} \text { F.wt }\end{array}$ & $\begin{array}{c}\% \\
\text { relative } \\
\text { to the } \\
\text { control }\end{array}$ & $\begin{array}{c}\text { Abscisic } \\
\text { acid } \mu \mathrm{g} / \mathrm{g} \\
\text { F.wt }\end{array}$ & $\begin{array}{c}\% \\
\text { relative } \\
\text { to the } \\
\text { control }\end{array}$ \\
\hline Control & 103.04 & 59.24 & 159.16 & 321.44 & 100.00 & 5.87 & 100.00 \\
\hline Lithovit at $250 \mathrm{mg} / 1$ & 152.03 & 87.07 & 217.07 & 456.17 & 141.91 & 4.59 & 78.19 \\
\hline Lithovit at $500 \mathrm{mg} / \mathrm{l}$ & 182.90 & 132.16 & 262.37 & 577.43 & 179.64 & 1.66 & 28.28 \\
\hline Amino acids at $2 \mathrm{ml} / \mathrm{l}$ & 137.37 & 131.78 & 252.62 & 521.77 & 162.32 & 3.37 & 57.41 \\
\hline Amino acids at $4 \mathrm{ml} / \mathrm{l}$ & 174.81 & 188.14 & 266.67 & 629.62 & 195.87 & 1.38 & 23.51 \\
\hline
\end{tabular}

\section{Anatomical characteristics:}

Data in Tables (5 and 6) and Figs. (1 and 2) obviously indicate the effect of different applied treatments on different anatomical traits of soybean leaf and stem. In this respect, most of these applied treatments showed positively impacts on most studied histological characteristics of soybean stem (i.e., stem diameter, thickness of cuticle layer, thickness of epidermis, collenchyma layers thickness , parenchyma layers thickness, thickness of cambial region, thickness of phloem, thickness of xylem, number of xylem rows/vascular cylinder, No. of xylem vessels/row, diameter of the widest xylem vessel, thickness of parenchymatous pith) as compared with the control. In addition, the studied histological features of soybean leaf (i.e., thickness of upper epidermis, thickness of lower epidermis, thickness of palisade tissue, thickness of spongy tissue, blade thickness, upper collenchyma layers thickness, lower collenchyma layers thickness, phloem thickness, xylem tissue thickness, number of xylem rows, thickness of widest xylem vessel, length of midrib vascular bundle, width of midrib vascular bundle, leaf midrib thickness) were increased with different applied treatments compared with the control. Lithovit at $500 \mathrm{mg} / \mathrm{l}$ and amino acids at 4 $\mathrm{ml} / \mathrm{l}$ treatments appeared to be the most effective treatments compared with the other applied and control treatments. In brief, application treatments of lithovit at $500 \mathrm{mg} / \mathrm{l}$ and amino acids at $4 \mathrm{ml} / \mathrm{l}$ recorded the highest values of the stem and leaf anatomical characteristics.

In general, the stimulatory effects of applied treatments upon the anatomy features of treated plants could be attributed to their effects upon cambium activity. Increases of cambium activity could mainly attributed to the increase of endogenous hormones level especially cytokinins and auxins (Ismaeil and Abd El-All, 2011) as well as the findings of the present study (Table,4).

These positive responses of different anatomical aspects to treatments were completely reversed upon vegetative and reproductive growth of treated plants. So, the present study revealed those increases of the vascular tissues i.e., xylem tissue, the route of nutrients and water translocation from roots to leaves and the phloem tissue, the pathway of different assimilates from leaves to seeds and other plant sinks, thereby, improvement of translocation events directly could be considered a direct reason for increment in the final seed yield.

Our results are in harmony with those reported by (Abd El-Aal, 2009) who found that foliar application with amino acids increased leaf and stem anatomical features of tomato plant. Also, (ElBadawy and Abd El-Aal, 2013) found that tryptophan foliar spray enhanced most of the leaf anatomical features of mango plant. 
Table 5. The mean counts and measurements of certain histological features of soybean (Glycine max L.) stems at 85 days after sowing during 2017 season.

\begin{tabular}{|c|c|c|c|c|c|}
\hline $\begin{array}{l}\text { Histological } \\
\text { Characteristics (micron) }\end{array}$ & Control & $\begin{array}{l}\text { Lithovit at } \\
250 \mathrm{mg} / 1\end{array}$ & $\begin{array}{c}\text { Lithovit at } \\
500 \mathrm{mg} / \mathrm{l}\end{array}$ & $\begin{array}{l}\text { Amino acids } \\
\text { at } 2 \mathrm{ml} / 1\end{array}$ & $\begin{array}{l}\text { Amino acids } \\
\text { at } 4 \mathrm{ml} / 1\end{array}$ \\
\hline Stem diameter & 3943 & 4374 & 5180 & 4391 & 5465 \\
\hline Thickness of cuticle layer & 5 & 5 & 4 & 4 & 4 \\
\hline Thickness of epidermis & 14 & 13 & 15 & 15 & 14 \\
\hline Collenchyma layers thickness & 174 & 229 & 228 & 187 & 214 \\
\hline Parenchyma layers thickness & 295 & 360 & 397 & 271 & 366 \\
\hline Thickness of cambial region & 15 & 19 & 24 & 17 & 20 \\
\hline Thickness of phloem & 176 & 213 & 272 & 188 & 241 \\
\hline Thickness of xylem & 441 & 465 & 607 & 594 & 672 \\
\hline Number of xylem rows/Vascular cylinder & 192 & 250 & 292 & 228 & 284 \\
\hline No. of xylem vessels/row & 7 & 13 & 14 & 10 & 12 \\
\hline Diameter of the widest xylem vessel & 45 & 38 & 40 & 31 & 42 \\
\hline Thickness of parenchymatous pith & 1534 & 1537 & 1885 & 1628 & 2113 \\
\hline
\end{tabular}

Table 6. The mean counts and measurements of certain histological features of soybean (Glycine max L.) leaves at 85 days after sowing during 2017 season.

\begin{tabular}{|c|c|c|c|c|c|}
\hline $\begin{array}{cc}\text { Histological } & \text { Treatments } \\
\text { Characteristics (micron) } & \\
\end{array}$ & Control & $\begin{array}{c}\text { Lithovit } \\
\text { at } 250 \mathrm{mg} / 1\end{array}$ & $\begin{array}{l}\text { Lithovit } \\
\text { at } 500 \mathrm{mg} / 1\end{array}$ & $\begin{array}{l}\text { Amino acids } \\
\text { at } 2 \mathrm{ml} / 1\end{array}$ & $\begin{array}{c}\text { Amino acids } \\
\text { at } 4 \mathrm{ml} / 1\end{array}$ \\
\hline Thickness of upper epidermis & 19 & 20 & 17 & 18 & 19 \\
\hline Thickness of lower epidermis & 16 & 13 & 15 & 14 & 15 \\
\hline Thickness of palisade tissue & 105 & 140 & 117 & 123 & 126 \\
\hline Thickness of spongy tissue & 208 & 305 & 298 & 283 & 260 \\
\hline Blade thickness & 348 & 478 & 447 & 438 & 420 \\
\hline Upper collenchyma layers thickness & 433 & 419 & 441 & 370 & 507 \\
\hline Lower collenchyma layers thickness & 351 & 220 & 267 & 305 & 316 \\
\hline Phloem thickness & 109 & 154 & 195 & 187 & 171 \\
\hline Xylem tissue thickness & 411 & 516 & 587 & 422 & 538 \\
\hline Number of xylem rows & 13 & 16 & 18 & 17 & 19 \\
\hline Thickness of widest xylem vessel & 38 & 44 & 43 & 39 & 41 \\
\hline Length of midrib vascular bundle & 520 & 670 & 782 & 609 & 709 \\
\hline Width of midrib vascular bundle & 736 & 895 & 912 & 850 & 906 \\
\hline Leaf midrib thickness & 1451 & 1472 & 1680 & 1458 & 1637 \\
\hline
\end{tabular}




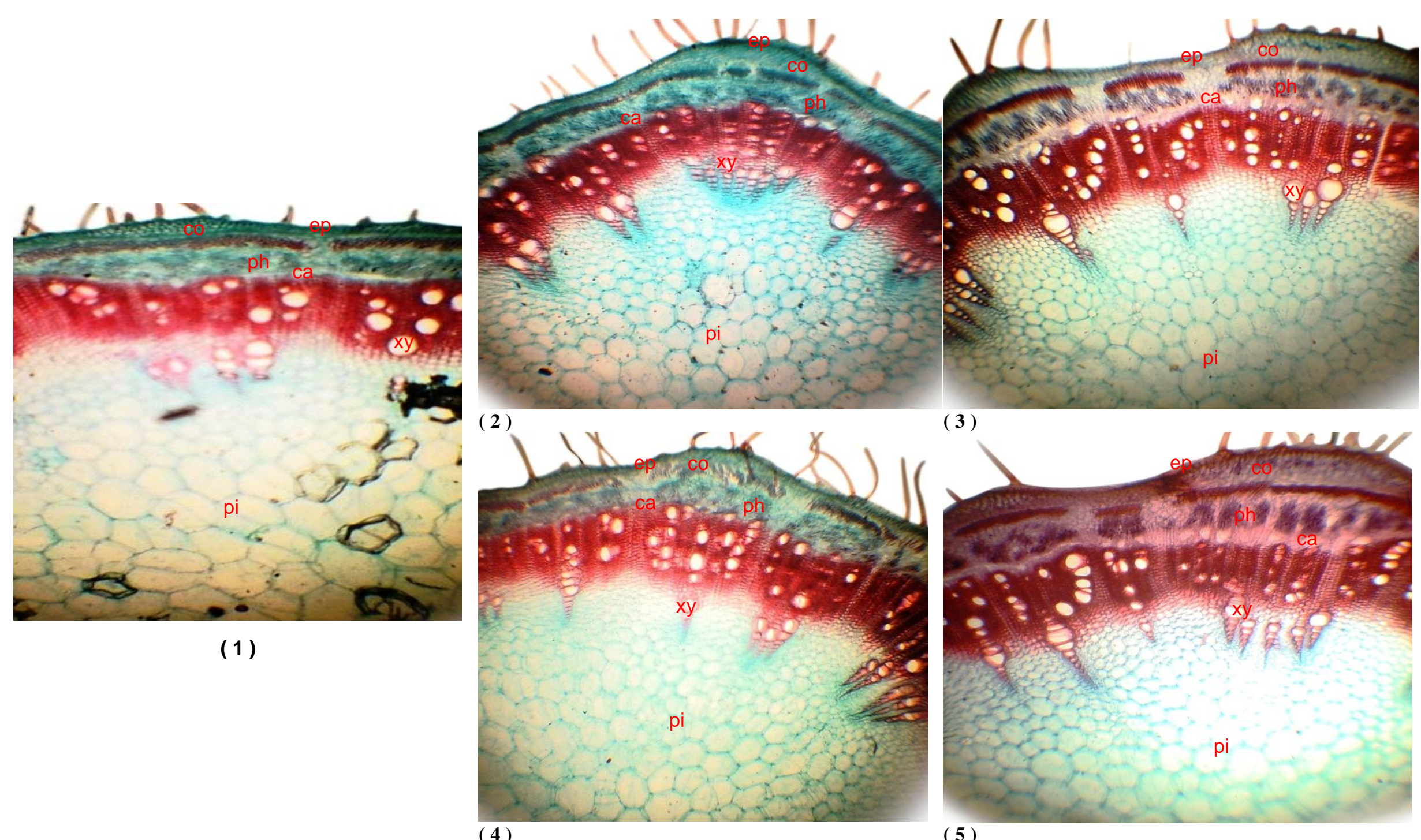

Fig. (1): Transverse sections $(X=40)$ through $4^{\text {th }}$ internode of Glycine max L. main stem at 85 days after sowing as affected by different applied treatments. Where: (1): Control $\quad$ (2): Lithovit at $250 \mathrm{mg} / \mathrm{l}$ (3): Lithovit at $500 \mathrm{mg} / \mathrm{l}$ (4): Amino acids at $2 \mathrm{ml} /$ (5): Amino acids at $4 \mathrm{ml} / \mathrm{l}$ $\mathrm{ep}=$ epidermis $\mathrm{co}=$ Cortex 


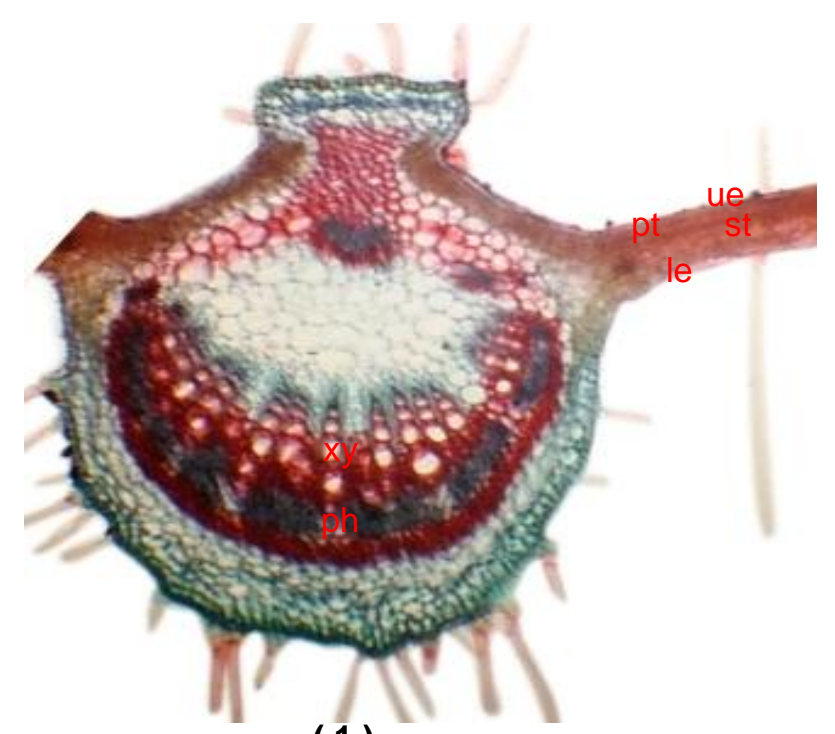

(1)

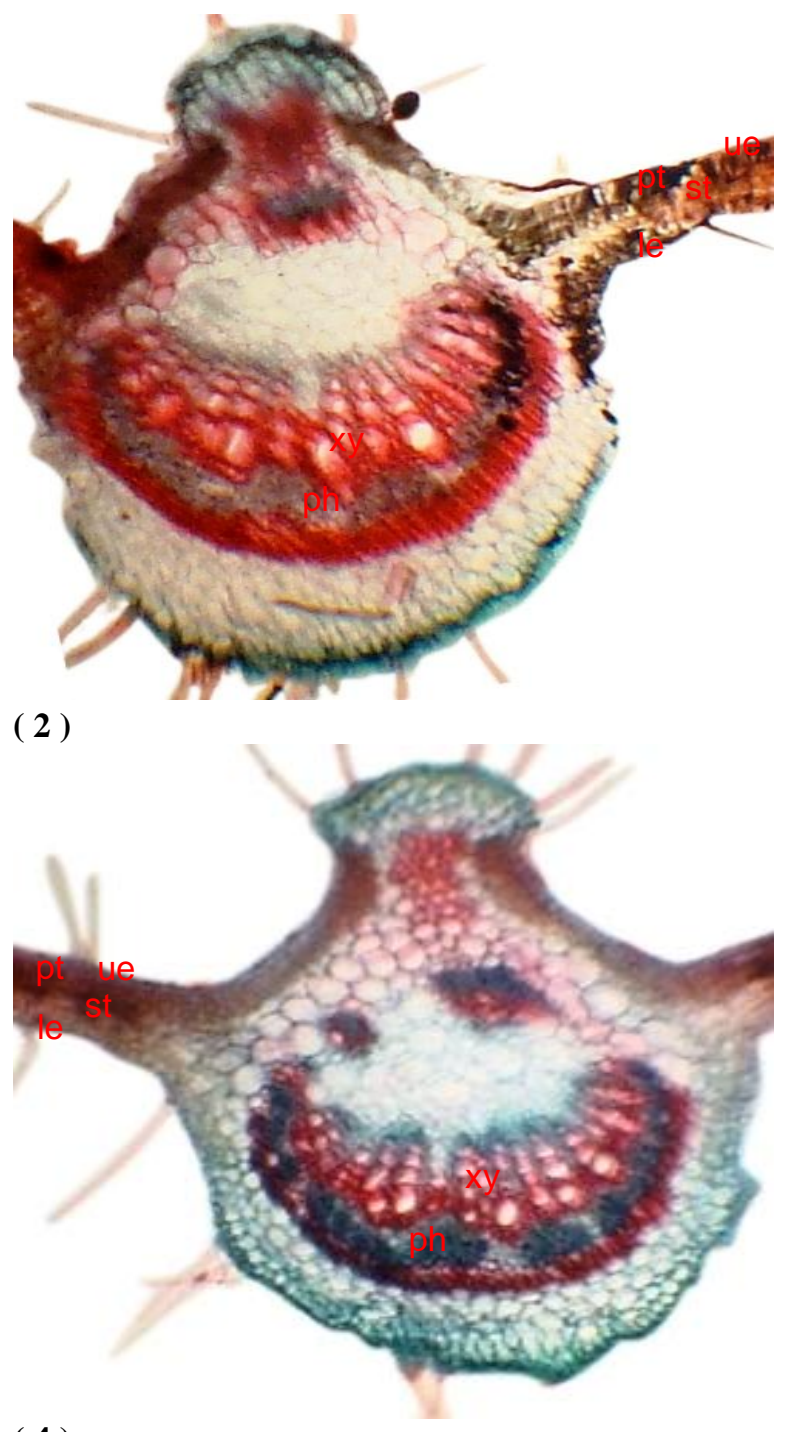

( 4 )

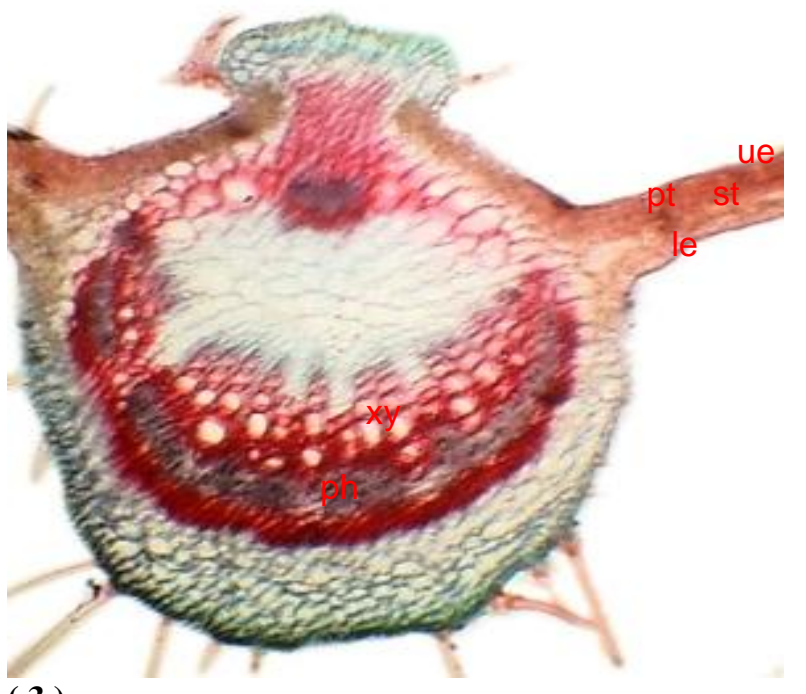

( 3 )

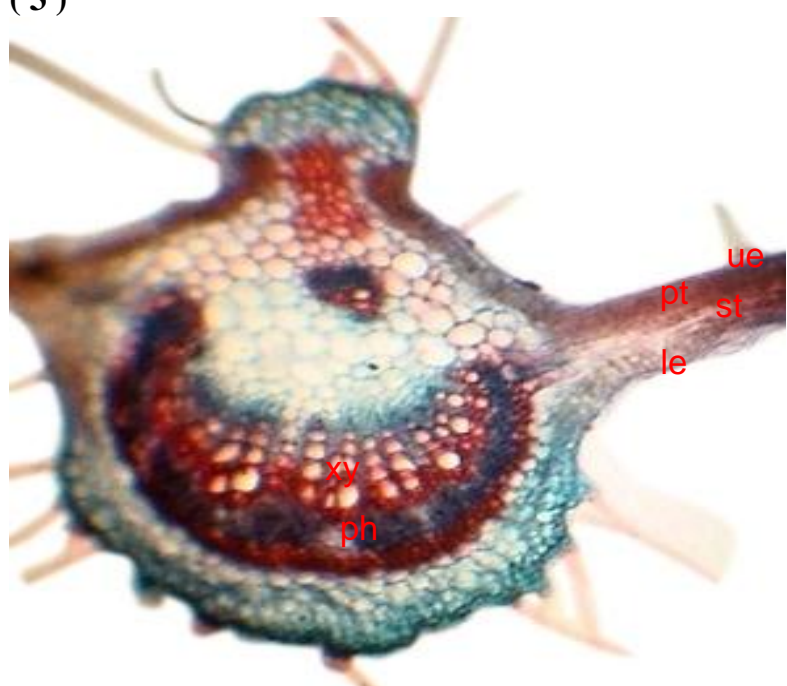

( 5 )

Fig. (2): Transverse sections $(X=40)$ through $4^{\text {th }}$ apical leaf of Glycine max $\mathrm{L}$. plant at 85 days after sowing as affected by different applied treatments.

$\begin{array}{lll}\text { Where: (1): Control } & \text { (2): Lithovit at } 250 \mathrm{mg} / \mathrm{l} & \text { (3): Lithovit at } 500 \mathrm{mg} / \mathrm{l}\end{array}$

(4): Amino acids at $2 \mathrm{ml} / \mathrm{l}$

(5): Amino acids at $4 \mathrm{ml} / \mathrm{l}$ $\mathrm{Ue}=$ Upper epidermis $\quad \mathrm{le}=$ Lower epidermis $\quad \mathrm{pt}=$ Palisade tissue $\mathrm{st}=$ Spongy tissue $\mathrm{ph}=$ phloem tissue $\mathrm{xy}=$ Xylem tissue 


\section{Yield and its components:}

\subsection{Flowering and seed yield attributes}

Recorded data in Table ( 7 ) illustrate that foliar application with lithovit at 250 and $500 \mathrm{mg} / \mathrm{l}$ and amino acids at 2 and $4 \mathrm{ml} / \mathrm{l}$ caused stimulatory effects on yield characteristics expressed as; number of flowers/plant, number of setted pods/plant, pods yield/plant, number of seeds/pod, weight of seeds/pod, 100 seeds weight $(\mathrm{g})$ and weight of seeds/plant $(\mathrm{g})$ compared with the control treatment in both seasons 2016 and 2017. These increases of yield attributes were gradually increased with increasing lithovit and amino acid rates.

In other words, lithovit and amino acids foliar applications enhanced soybean yield by influencing the number of seeds per plant and seed weight. lithovit and amino acids improved photosynthesis and assimilates transportation to sinks and finally increased seed yield.

In this respect, the most superior treatments were the lithovit at $500 \mathrm{mg} / \mathrm{l}$ followed by amino acids at 4 $\mathrm{ml} / \mathrm{l}$ then lithovit at $250 \mathrm{mg} / \mathrm{l}$, respectively at the two seasons.
This stimulation of seed yield production is considered as a direct result of the vigorous growth including the photosynthetic area (Table,1) and photosynthetic pigments in leaves (Table,2) and growth promoters (Table,4) of soybean plants during different stages of growth.

These results are in agreement with those of (Vahedi, 2011) who reported that soybean higher yield could be obtained by foliar spray by nutrient elements. (Tousi et al., 2014) showed that spray application of nano-Fe chelate produced the highest grain and yield of soybean.

(Zewail, 2014) showed that foliar application on common bean plant with amino acids at $4 \mathrm{ml} / \mathrm{l}$ increased yield components i.e., number of pods/plant, pod weight (g), number of seeds per pod, number of fully seeds /plant, weight of 100 seeds (g), number of seeds/ plant, seed yield (g)/plant and the harvest index. (Sadak $\boldsymbol{e t}$ al., 2015) stated that amino acid application at $1500 \mathrm{mg} \mathrm{L}^{-1}$ as foliar spray significantly improved seed yield of faba bean plant.

(Abd El Ghafer et al., 2016) mentioned that foliar application with lithovit $0.5 \mathrm{~g} / \mathrm{l}$ significantly increased yield aspects of onion plants.

Table 7. Effect of lithovit and amino acids on flowering and yield and its components of soybean plant during 2016 and 2017 seasons.

\begin{tabular}{|c|c|c|c|c|c|c|c|c|c|}
\hline Characteristics & $\begin{array}{c}\text { Number } \\
\text { of } \\
\text { flowers/ } \\
\text { plant }\end{array}$ & $\begin{array}{c}\text { Shedding } \\
\% \text { of } \\
\text { flower }\end{array}$ & $\begin{array}{c}\text { Number } \\
\text { of setted } \\
\text { pods/plant }\end{array}$ & $\begin{array}{c}\text { Setted } \\
\text { pods } \\
\%\end{array}$ & $\begin{array}{c}\text { Pods } \\
\text { weight } \\
\text { /plant } \\
\text { (g) }\end{array}$ & $\begin{array}{l}\text { Number } \\
\text { of } \\
\text { seeds/pod }\end{array}$ & $\begin{array}{l}\text { Weight of } \\
\text { seeds/pod }\end{array}$ & $\begin{array}{l}\text { Seeds } \\
\text { yield } \\
\text { /plant } \\
(\mathrm{g})\end{array}$ & $\begin{array}{c}100 \\
\text { seeds } \\
\text { weight } \\
(\mathrm{g})\end{array}$ \\
\hline & \multicolumn{9}{|c|}{$1^{\text {st }}$ season (2016) } \\
\hline Control & 253.87 & 52.26 & 121.20 & 47.74 & 72.40 & 2.30 & 0.356 & 23.17 & 15.94 \\
\hline Lithovit at $250 \mathrm{mg} / \mathrm{l}$ & 260.97 & 37.73 & 162.51 & 62.27 & 86.29 & 2.71 & 0.471 & 47.72 & 17.80 \\
\hline Lithovit at $500 \mathrm{mg} / \mathrm{l}$ & 275.22 & 35.86 & 176.53 & 64.14 & 134.46 & 2.78 & 0.582 & 50.36 & 20.13 \\
\hline Amino acids at $2 \mathrm{ml} / 1$ & 272.48 & 48.85 & 139.38 & 51.15 & 83.13 & 2.42 & 0.455 & 27.95 & 19.00 \\
\hline Amino acids at $4 \mathrm{ml} / \mathrm{l}$ & 268.63 & 42.56 & 154.29 & 57.44 & 114.51 & 2.58 & 0.560 & 48.56 & 21.50 \\
\hline \multirow[t]{2}{*}{ L.S.D. } & 8.20 & 11.34 & 16.45 & 6.17 & 11.03 & 0.22 & 0.105 & 13.95 & 2.01 \\
\hline & \multicolumn{9}{|c|}{$2^{\text {nd }}$ season (2017) } \\
\hline Control & 205.31 & 43.25 & 116.52 & 56.75 & 80.67 & 2.11 & 0.338 & 30.51 & 16.14 \\
\hline Lithovit at $250 \mathrm{mg} / \mathrm{l}$ & 226.22 & 31.12 & 155.81 & 68.88 & 90.21 & 2.28 & 0.407 & 33.48 & 17.54 \\
\hline Lithovit at $500 \mathrm{mg} / \mathrm{l}$ & 258.41 & 33.15 & 172.76 & 66.85 & 123.41 & 2.93 & 0.594 & 52.28 & 20.77 \\
\hline Amino acids at $2 \mathrm{ml} / 1$ & 262.13 & 44.91 & 144.40 & 55.09 & 98.72 & 2.15 & 0.405 & 45.57 & 18.46 \\
\hline Amino acids at $4 \mathrm{ml} / \mathrm{l}$ & 279.33 & 43.35 & 158.25 & 56.65 & 122.33 & 2.79 & 0.578 & 43.09 & 20.33 \\
\hline $\begin{array}{ll}\text { L.S.D. } & 0.05\end{array}$ & 21.07 & 5.82 & 12.16 & 4.14 & 8.75 & 0.18 & 0.087 & 11.40 & 1.56 \\
\hline
\end{tabular}

5.2. Seed oil percentage and fatty acids composition of soybean oil:

Data in Table (8) reveal that foliar spraying of soybean plants with lithovit at 250 and $500 \mathrm{mg} / \mathrm{l}$ and amino acids at 2 and $4 \mathrm{ml} / \mathrm{l}$ caused increases in seed oil \% compared to unsprayed plants in the growing season of 2017. Also, spraying of lithovit at 500 and $250 \mathrm{mg} / \mathrm{l}$, respectively produced higher values than spraying as amino acids at 2 and $4 \mathrm{ml} / \mathrm{l}$ in the aforementioned character.

In summary, under the nano-treatments, the highest oil yield was obtained from the lithovit at 500 $\mathrm{mg} / \mathrm{l}$ application. The effect of nano-particles on oil yield was associated with fertilization rate. The oil yield decreases associated with increasing rate of amino acids application compared with nano treated plants.

In few words, the opposite trend was observed for oil yield with increasing amino acids application rate, confirming the inverse relationship between protein content as abovementioned in (Table,3) and oil percentages (Table,8). There are several reports on decreased seed oil content with increasing nitrogen uptake (Zheljazkov et al., 2009 and Mohammadi and Rokhzadi 2012). High availability of nitrogen decreased the carbohydrate availability for oil synthesis, but protein synthesis is increased, (Rathke et al., 2005). Change in nitrogen sources during seed maturation affects the synthesis of fatty acids and, therefore, their final proportion in the oils of mature 
seeds. The reason for this correlation relates to the competition for carbon skeletons during carbohydrate metabolism, (Bhatia and Rabson, 1976). The synthesis of amino and fatty acids requires carbon compounds from the decomposition of carbohydrates. Since the carbohydrate content of proteins is lower than that of oil, (Lambers and Poorter, 1992) increased $N$ supply intensifies the synthesis of proteins at the expense of fatty acid synthesis and thus reduces the oil content of the seed.

Seed composition constituents were reported to be genetically controlled, (Helms and Orf, 1998). However, seed composition have also shown to be affected by nutrients, (Bellaloui et al., 2009).

The concentration of unsaturated fatty acids in soybean is important with respect to its final uses and market price. Oleic, linolenic and linoleic acids are considered as unsaturated fatty acids. The same data in (Table, 8) show the effect of different applications on the saturated fatty acids myristic, palmitic, arachidic, behenic and stearic acids (TS) compared with the unsaturated fatty acids oleic, linoleic, linolenic and cicosotonoic (US). Higher ratio means higher unsaturated fatty acids were produced. For amino acids at $2 \mathrm{ml} / \mathrm{l}$, lithovit at $500 \mathrm{mg} / \mathrm{l}$ and lithovit at $250 \mathrm{mg} / \mathrm{l}$ applications, the ratios were 1: $5.62,1$ : 5.56 and 1: 5.51while, the control had the lowest ratio (1: 5.07). Lower ratios means lower \% of oleic, linoleic and linoleic acids and higher percentage of palmitic and stearic acids produced. Applications of different treaments increased the unsaturated to saturated fatty acids ratios compared with the control.

The increase of oil \% and the unsaturated fatty acids with the lithovit and amino acids application rates compared with the control indicate that the different applications had positive effects on seed composition constituents.
The increases in seed oil and unsaturated fatty acids \% may be attributed to the enhancing effect of lithovit (nano particles) and amino acids on the enzymes of biosynthetic and desaturation pathways of fatty acids metabolism of soybean oil. In this respect, Iron is necessary for the formation of ferredoxin which play an important role in NADPH as electron donor to stearyl desaturase in higher plants, (Marschner, 1995). Many investigators obtained similar results, (Vahedi, 2011) concluded that soybean higher yield and quality as well as its oil could be obtained by foliar spray of nutrient elements. (Tousi et al., 2014) showed that spray application of nano-Fe chelate produced the highest oleic acid and oil yield of soybean plants. (Khater, 2015) showed that spraying Mentha piperita L. plant with magnetic- nanoparticles (MNPs) increased significantly the essential oil composition. (Mohammadi, 2015) observed that treating soybean plant with nano-iron chelate fertilizer significantly increased oil content and fatty acids (oleic, linoleic and linolenic acids (\%)

Conclusion: This study demonstrated that Lithovit as nano particles $(\mathrm{Ca}, \mathrm{Mg}$ and $\mathrm{Fe}$ nano particles) and amino acids foliar applications played a critical role in enhancing growth, yield and seeds oil production of soybean plant. Therefore, Lithovit at $500 \mathrm{mg} / \mathrm{l}$ and amino acids at $4 \mathrm{ml} / \mathrm{l}$ foliar application is recommended in soybean fields. The fatty acid composition was affected by applied treatments. Our results suggest that the amino acids at $2 \mathrm{ml} / \mathrm{l}$ and Lithovit at $500 \mathrm{mg} / \mathrm{l}$ treatments increased the unsaturated fatty acids of soybean. Therefore, this agronomic factor could be used to produce soybean oil with a decreased saturated fatty acids.

Table 8. Effect of lithovit and amino acids on oil \% and fatty acids composition of soybean oil in 2017 season.

\begin{tabular}{|c|c|c|c|c|c|c|c|c|c|c|c|c|c|}
\hline \multirow[b]{2}{*}{ Treatments } & \multirow{2}{*}{$\begin{array}{l}\text { seed } \\
\text { oil \% }\end{array}$} & \multicolumn{9}{|c|}{$\%$ of fatty acid composition } & \multirow{2}{*}{$\begin{array}{l}\text { Total } \\
\text { saturated }\end{array}$} & \multirow{2}{*}{$\begin{array}{l}\text { Total } \\
\text { unsaturated }\end{array}$} & \multirow{2}{*}{ TS:US } \\
\hline & & $\begin{array}{c}\mathrm{C} \\
14: 0\end{array}$ & $\begin{array}{c}\mathrm{C} \\
16: 0\end{array}$ & $\begin{array}{c}\mathrm{C} \\
18: 0\end{array}$ & $\begin{array}{c}\mathrm{C} \\
20: 0\end{array}$ & $\begin{array}{c}\mathrm{C} \\
22: 0\end{array}$ & $\begin{array}{c}\mathrm{C} \\
18: 1\end{array}$ & $\begin{array}{c}\mathrm{C} \\
18: 2\end{array}$ & $\begin{array}{c}\mathrm{C} \\
18: 3\end{array}$ & $\begin{array}{c}C \\
20: 1\end{array}$ & & & \\
\hline Control & 20.59 & 0.13 & 10.12 & 5.22 & 0.56 & 0.29 & 23.24 & 53.30 & 5.98 & 0.30 & 16.32 & 82.82 & $\begin{array}{c}1: \\
5.07\end{array}$ \\
\hline $\begin{array}{l}\text { Lithovit at } \\
250 \mathrm{mg} / \mathrm{l}\end{array}$ & 22.37 & 0.15 & 10.04 & 4.42 & 0.46 & 0.26 & 23.71 & 54.14 & 6.32 & 0.34 & 15.33 & 84.51 & $\begin{array}{c}1: \\
5.51\end{array}$ \\
\hline $\begin{array}{l}\text { Lithovit at } \\
500 \mathrm{mg} / \mathrm{l} \\
\end{array}$ & 23.95 & 0.15 & 9.80 & 4.50 & 0.48 & 0.27 & 23.74 & 54.02 & 6.33 & 0.36 & 15.20 & 84.45 & $\begin{array}{c}1: \\
5.56 \\
\end{array}$ \\
\hline $\begin{array}{l}\text { Amino acids } \\
\text { at } 2 \mathrm{ml} / \mathrm{l}\end{array}$ & 21.78 & 0.15 & 10.00 & 4.24 & 0.44 & 0.27 & 23.62 & 54.04 & 6.26 & 0.32 & 15.10 & 84.24 & $\begin{array}{c}1: \\
5.62 \\
\end{array}$ \\
\hline $\begin{array}{l}\text { Amino acids } \\
\text { at } 4 \mathrm{ml} / \mathrm{l}\end{array}$ & 21.67 & 0.14 & 9.92 & 4.66 & 0.45 & 0.27 & 23.52 & 53.96 & 6.22 & 0.35 & 15.44 & 84.05 & $1: 5.44$ \\
\hline
\end{tabular}

\section{Where:}

Myristic (C 14:0) Palmitic (C 16:0) Stearic (C 18:0) Arachidic (C 20:0) Behenic (C 22:0) Oleic (C 18:1)

Linoleic (C 18:2) Linolenic ( $\left.\mathrm{C}_{18: 3}\right) \quad$ Cicosotonoic ( $\left.\mathrm{C}_{20: 1}\right) \quad$ TS: Total saturated US: Total unsaturated 


\section{References}

A.O.A.C. (2005): Official Methods of Analysis. $18^{\text {th }}$ ed. Association of Official Analytical Chemists. Washington, DC, USA.

Abd El-Ghafar, M. S.; M. T. Al-Abd; A. A. Helaly and A. M. Rashwan (2016): Foliar application of lithovit and rose water as factor for increasing onion seed production. Nat. Sci., 14(3): 53-61.

Abdel Nabi, H. M. A.; K. K. Dawa; E. I. El-Gamily and Y. F. E. Imryed (2017): Effect of magnetic water, foliar application with nano material and nitrogen levels on productivity and quality of head lettuce. Int. J. Adv. Res. Biol. Sci., 4(5): 171-181.

Abd-El-Aal, M. M. (2009): Improvement of tomato productivity by using certain natural materials. Ph.D Thesis, Fac. of Agric. Benha Univ.

Abo Basha, D. M. R. and H. I. El-Aila (2015): Response of foliar spraying with amino acids and integrated use of nitrogen fertilizer on radish (Raphanus sativus L.) plant. Int. J. Chem. Tech. Res., 8(11): 135-140.

Abo Sedera, F. A.; A. A. Abd El-Latif; L. A. A. Bader and S. M. Rezk (2010): Effect of NPK mineral fertilizer levels and foliar application with humic and amino acids on yield and quality of strawberry. Egyp. J. of Appl. Sci., 25:154-169.

Agrawal, M. and S. S. Deepak (2003): Physiological and biochemical responses of two cultivars of wheat to elevated levels of $\mathrm{CO}_{2}$ and $\mathrm{SO}_{2}$ singly and in combination. Environ. Pollut., 121:189197.

Allison, M. F.; J. H. Fower and E. J. Allen (2001): Factors affecting the magnesium nutrition of potatoes (Solanum tuberosum L.). J. Agric. Sci. Cambridge, 137:397- 409.

Azevedo Neto, A. D.; J. T. Prisco; J. Eneas-Filho; J. V. R. Medeiros and E. Gomes-Filho (2005): Hydrogen peroxide pretreatment induces stress acclimation in maize plants. J. Plant Physiol., 162: 1114-1122.

Bellaloui, N.; J. E. Hanks; D. K. Fisher and A. Mengistu (2009): Soybean seed composition is influenced by with-in field variability in soil nutrients. Crop Management,10.1094/CM-120301-RS.

Bhatia, C. R. and R. Rabson (1976): Bioenergetic considerations in cereal breeding for protein improvement. Sci., 194:1418-1421.

Buchanan, B. B.; W. Gruissem and R. L. Jones (2000): Biochemistry and molecular biology of plants. Rockville, MD: American Society of Plant Physiologists.

Carmen, B.; R. Sumalan; S. Gadea and S. Vatca (2014): Physiological indicators study involved in productivity increasing in tomato. Proenvironment, 7: 218-224.
DeLille, J. M.; P. C. Sehnke and R. J. Ferl (2011): The Arabidopsis 14-3-3 family of signaling regulators. Plant Physiol. 126: 35-38.

Dubois, M.; K. A. Gilles; J. Hamilton; P. A. Rebens and F. Smith (1956): Colorimetric method for determination of sugars and related substances. Annals of Chem., 28:350-356.

El-Atabany, S. A. M. (2015): Effect of sowing system and foliar spray by safety natural materials on yield and quality of snap bean. Ph.D Thesis, Fac. Agric. Benha Univ.

El-Badawy, H. E. M. and M. M. M. Abd El-Aal (2013): Physiological response of keitt mango (Mangifera indica L.) to kinetin and tryptophan. J. Appl. Sci. Res., 9(8):4617-4626.

El-Ghamry, A. M.; K. M. Abd El-Hai and K. M. Ghoneem (2009): Amino and humic acids promote growth, yield and disease resistance of faba bean cultivated in clayey soil. Austr. J. of Basic and Appl. Sci., 3(2):731-739.

El-Zohiri, S. S. M. and Y. M. Asfour (2009): Effect of some organic compounds on growth and productivity of some potato cultivars. Annals of Agric. Sci., Moshtohor, 47 (3): 403-415.

Haq, M. U. and A. P. Mallarino (2005): Respones of soybean grain oil and protein concentrations to foliar and soil fertilization. Agron. J., 97: 910918.

Helms T. C. and J. H. Orf (1998): Protein, oil, and yield of soybean lines selected for increased protein. Crop Science, 38 (3):707-711.

Hildebrandt, T. M.; A. Nunes-Nesi; W. L. Araújo and H. P. Braun (2015): Amino acid catabolism in plants. Mol. Plant, 8:1563-1579.

Horneck, D. A. and D. Hanson (1998): Determination of potassium and sodium by Flame Emission Spectrophotometry. In handbook of reference methods for plant analysis, 153-155.

Horneck, D. A. and R. O. Miller (1998): Determination of total nitrogen in plant tissue. In handbook of reference methods for plant analysis. Kalra Y.P.(Ed.):75-83.

Ismaeil, F. H. M. and M. M. Abd El-All (2011): Effect of some growth regulators and antioxidants on growth, yield and seed chemical composition of faba bean plants. J. Plant Production, Mansoura Univ., 2 (11): 1563 -1577.

Jackson, M. L. (1967): Soil chemical analysis. Printice Hallpvt. Itd. India, 398.

Johanson, D. V. (1940): Plant microtechnique. New York and London McGrow- Hill Book Co. Inc., 27-154.

Khaledian, M. S.; K. Mohammadi and M. Javaheri (2014): Grain yield and yield components of soybean affected by integrated fertilization methods. Int. J. Agric. Forest., 4:1-3.

Khater, M. S. (2015): Magnetic- nanoparticles effects on growth and essential oil of peppermint. Int. J. Curr. Sci., 4 (2): 140-144. 
Kim, E.; S. Hwang and I. Lee (2016): SoyNet: a database of co-functional networks for soybean (Glycine $\max$ L.). Nucleic Acids Res., (1): 1-13.

Koshioka, M.; J. Harda; M. Noma; T. Sassa; K. Ogiama; J. S. Taylor; S. B. Rood; R. L. Legge and R. P. Pharis (1983): Reversed - phase C18 high performance liquid chromatography of acidic and conjugated gibbberellins. J. Chromatgr., 256:101-115.

Kowalczyk, K. and T. Zielony (2008): Effect of amino plant and asahi on yield and quality of lettuce grown on rock wool. Conf. of Biostimulators in Modern Agriculture, Warsaw, Poland.

Lambers, H. and H. Poorter (1992): Inherent variation in growth rate between higher plants: a search for physiological causes and ecological consequences. Adv. Ecol. Res., 23:187-261.

Liu Xing, Q.; H. Y. Chen; N. Qin-xue and L. K. Seung (2008): Evaluation of the role of mixed amino acids in nitrate uptake and assimilation in leafy radish by using $\mathrm{N}^{15}$-labeled nitrate. Agricultural Sciences in China,7 (10):1196-1202.

Liu, X. M.; F. D. Zhang; S. Q. Zhang; X. S. He; R. Fang; Z. Feng and Y. Wang (2005): Responses of peanut to nano-calcium carbonate. Plant Nutrition and Fertilizer Sci., 11:3-9.

Maeda, H. and N. Dudareva (2012): The shikimate pathway and aromatic amino acids biosynthesis in plants. Annu. Rev. Plant Biol., 63:73-105.

Malakouti, M. and M. Tehrani (2005): Micronutrient role in increasing yield and improving the quality of agricultural products. $1^{\text {st }} \mathrm{ed}$. Tarbiat Modarres Press, Tehran.

Marschner, H. (1995): Mineral Nutrition of Higher Plants, $2^{\text {nd }}$ ed. Academic press, New York, USA.

Maswada, H. F. and L. A. Abd El-Rahman (2014): Inducing salinity tolerance in wheat plants by hydrogen peroxide and lithovit "a nano$\mathrm{CaCO}_{3}$ fertilizer". J. Agric. Res. Kafr El-Sheikh Univ., 40 (4): 696-719.

Mohammadi, K. (2015): Grain oil and fatty acids composition of soybean affected by nano-iron chelate, chemical fertilizers and farmyard manure, Archives of Agronomy and Soil Science, 61 (11): 1593-1600.

Mohammadi, K. and A. Rokhzadi (2012): An integrated fertilization system of canola (Brassica napus L.) production under different crop rotations. Ind. Crop Prod., 37:264-269.

MoisăR, B. V. (2015): Study of the effect of several natural fertilizers on the seedlings leaf area for some tomato cultivars. J. Hort. Forestry Biotechnol., 19(2):77-81.

Naderi, M. R. and A. Danesh Shahraki (2013): Nanofertilizers and their roles in sustainable agriculture. Int. J. Agric. Crop Sci., 19:22292232.

Nicander, B. U. S.; P. Bjorkman and E. Tillberg (1993): Immyno affinity co-purification of cytokinins and analysis by high-performance liquid chromatography with ultra violet spectrum deterction. Planta, 189: 312-320.

Pratelli, R. and G. Pilot (2014): Regulation of amino acid metabolic enzymes and transporters in plants. J. Exp. Bot., 65: 5535-5556.

Rathke, G.W.; O. Christen and W. Diepenbrock (2005): Effects of nitrogen source and rate on productivity and quality of winter oilseed rape (Brassica napus L.) grown in different crop rotations. Field Crops Res., 94:103-113

Sabina, P. D. (2013): Research concerning the use of some seed and material preparation method in the production of biological material in generative Koelreuteria paniculata Laxm. J. Hort. Forestry Biotechnol., 17: 185-188.

Sadak, M. S. H.; M.T. Abd El-Hamid and U. Schmidhalter (2015): Effect of foliar application of amino acids on plant yield and physiological parameters in bean plants irrigated with seawater. Acta Biol. Colomb., 20(1):141-152.

Saeed, M. R.; A. M. Kheir and A. A. Al-Sayed (2005): Supperssive effect of some amino acids against Meloidogyne incognita on soybeans. J. Agric. Sci. Mansoura Univ., 30 (2): 1097 -1103.

Sandell, R. (1950): Colorimetric determination of traces of metal $2^{\text {nd }} \mathrm{Ed}$. Interscience pub. Inc. New York.

Sass, J. E. (1951): Botanical micro technique. Iowa State College Press, Ames, Iowa., 228.

Schwab, W. and T. Raab (2004): Developmental changes during strawberry fruit ripening and physico-chemical changes during postharvest storage. In: Dris, R., Jain,S.M. (Eds.), Production Practices and Quality Assessment of Food Crops, 'Quality handling and Evaluation',Kluwer Academic Publishers, Netherlands, 3: 341-369.

Shallan, M. A.; H. M. M. Hassan; A. A. M. Namich and A. A. Ibrahim (2016): The influence of lithovit fertilizer on the chemical constituents and yield characteristics of cotton plant under drought stress. Int. J. of Chem. Tech. Res., 9 (8): 1-11.

Sheykhbaglou, R. ; M. Sedghi; M. T. Shishevan and R. S. Sharifi (2010): Effects of nano-iron oxide particles on agronomic traits of soybean, Not. Sci. Biol., 2 (2):112-113.

Sink, J. D.; S. L. Walkins; J. H. Zeigler and R. C. Miller (1964): Analysis of fat by gas liquid chromatography. J. of Anim. Sci., 23:111-121.

Snedecor, G.W. and W. G. Cocharn (1991): Statistical methods. $8^{\text {th }}$ E.d., lowa State Univ. Press, Lowa, USA.

Thorn, A. J. and L. M. Rogan (2015): The effects of lithovit on production and returns in a Hayward kiwifruit orchard. Grower Services Manager, 1: $1-13$.

Tousi, P.; M. Tajbakhsh and M. Esfahani (2014): Effect of spray application of Nano-Fe chelate, amino acid compounds and magnetic water on protein content and fatty acids composition of oil 
of soybean (Glycine max L.) in different harvest time. Iranian J. of Crop Sci., 16(2): 125-136.

Vahedi, A. (2011): The effects of micronutrient application on soybean seed yield and on seed oil and protein content. J. Am. Sci., 7(6) :672-677.

Wang, L.; Z. Feng and J. K. Schjoerring (2013): Effects of elevated atmospheric $\mathrm{CO}_{2} \mathrm{On}$ physiology and yield of wheat (Triticum aestivum L.): A meta-analytic test of current hypotheses. Agric. Ecosyst. Environ., 178: 57-63.

Wettstein, D. (1957): Chlorophyll, Letal and dersubmicro-Spische Formmech Sellderplastideu, Exptl. Cell Res., 12:427.
Zewail, R. M. Y. (2014): Effect of seaweed extract and amino acid on growth and productivity and some biocostituents of common bean (Phaseolus vulgaris L.) plants, J. Plant Production, Mansoura Univ., 5(8):1441-1453.

Zheljazkov, V. D.; B.A. Vick; B.S. Baldwin; N. Buehring; T. Astatkie and B. Johnson (2009): Oil content and saturated fatty acids in sunflower as a function of planting date, nitrogen rate and hybrid. Agron. J., 101:1003-1011.

Zhu, H.; J. Q. Han and Y. Jin (2008): Uptake, translocation, accumulation of manufactured iron oxide nanoparticles by pumpkin plants. J. Environ. Monit., 10:713-717.

\footnotetext{
تأثير الرش الورقى بالليثوفيت والأحماض الأمينية على النمو والمكونات الحيوية والصفات التشريحية والمحصول لنبات فول الصويا

محمد محمد محمود عبد العال ، رانيا سعيد معوض عيد

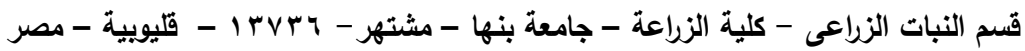

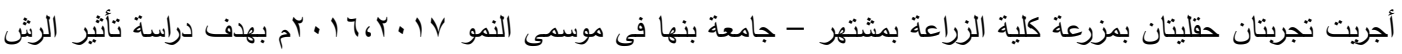

الورقى بالليثوفيت بتركيز . 0، ـ0 ملجم/لتز والأحماض الأمينية بتركيز ع، كل/لتز بالإضافة إلي معاملة الكنترول (ماء الصنبور) على صفات

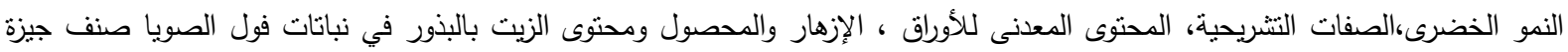

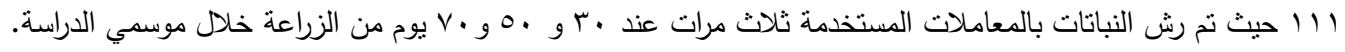

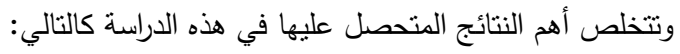
أعطت كل المعاملات زيادة معنوية فى صفات النمو الخضرى منت طول وقطر الساق وعدد الأفرع للنبات وعدد ومساحة الأوراق/للنبات

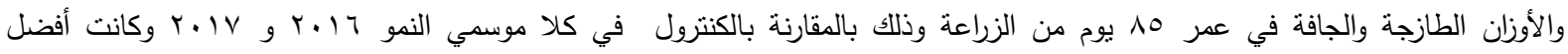

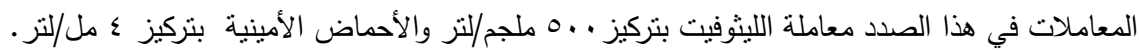

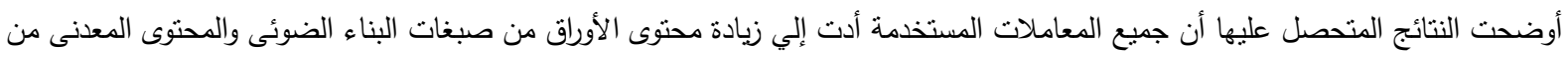
عناصر النيتروجين ، الفوسفور ، البوتاسيوم ، الكالسيوم ، الماغنسيوم وكذلك عنصر الحديد كما أدت أيضا إلى زيادة المحتوى من البروتين

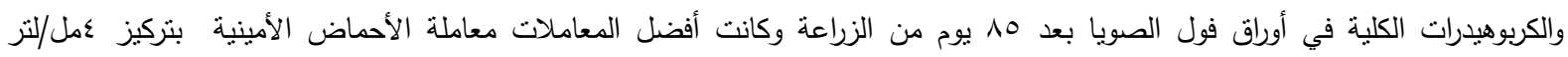

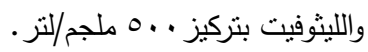

أظهرت النتائج المتحصل عليها أن المعاملات المختلفة المستخدمة أدت إلي زيادة كبيرة في التركيز الهرموني الداخلى للستيوكينيات والجبريللينات والأوكسينات بينما أدت إلي نقص واضح في المثبطات الداخلية منل حمض الأبسيسك ، كما أدت المعاملات المختلفة المستخدمة إلى تغيرات واضحة فى الصفات التشريحية لأوراق وسيقان نبات فول الصويا وكانت أفضل المعاملات في هذا الصدد معاملة الأحماض الأمينية

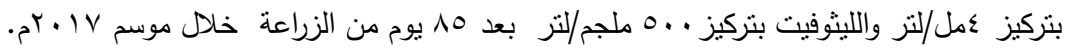
أدي إستخدام المعاملات المختلفة إلي تقليل نسبة تساقط الأزهار وزيادة المحصول الكلى معبراً عنه بعدد ووزن القرون للنبات ومحصول البذور ومحتوى الزيت بالبذور ونسب الأحماض الدهنية الغير مشبعة للمشبعة وكانت أفضل المعاملات هى الليثوفيت بتركيز . .0 ملجم/لتز والأحماض الأمينية بتركيز عمل/لتز مقارنة بالنباتات الغير معاملة.
} 
